\title{
The pollutant emissions from diesel-engine vehicles and exhaust aftertreatment systems
}

\author{
İbrahim Aslan Reşitoğlu • Kemal Altinişik • \\ Ali Keskin
}

Received: 28 March 2014/Accepted: 21 May 2014/Published online: 11 June 2014

(c) The Author(s) 2014. This article is published with open access at Springerlink.com

\begin{abstract}
Diesel engines have high efficiency, durability, and reliability together with their low-operating cost. These important features make them the most preferred engines especially for heavy-duty vehicles. The interest in diesel engines has risen substantially day by day. In addition to the widespread use of these engines with many advantages, they play an important role in environmental pollution problems worldwide. Diesel engines are considered as one of the largest contributors to environmental pollution caused by exhaust emissions, and they are responsible for several health problems as well. Many policies have been imposed worldwide in recent years to reduce negative effects of diesel engine emissions on human health and environment. Many researches have been carried out on both diesel exhaust pollutant emissions and aftertreatment emission control technologies. In this paper, the emissions from diesel engines and their control systems are reviewed. The four main pollutant emissions from diesel engines (carbon monoxide-CO, hydrocarbons-HC, particulate matter-PM and nitrogen oxides- $\mathrm{NO}_{\mathrm{x}}$ ) and control systems for these emissions (diesel oxidation catalyst, diesel particulate filter and selective catalytic reduction) are discussed. Each type of emissions and control systems is comprehensively examined. At the same time, the legal restrictions on exhaust-gas emissions around the world and the effects of exhaust-gas emissions on human health and environment are explained in this study.
\end{abstract}

\footnotetext{
İ. A. Reşitoğlu $(\square) \cdot$ A. Keskin

Tarsus Technology Faculty, Mersin University, 33500 Mersin,

Turkey

e-mail: aslanresitoglu@gmail.com

K. Altinişik

Department of Mechanical Engineering, Selcuk University, 42003 Konya, Turkey
}

Keywords Diesel engine $\cdot$ Emission - Emission control system $\cdot$ SCR $\cdot$ DOC $\cdot$ DPF

\section{Introduction}

Climate change is being counted as a global environmental threat caused by people. It is seen as the second most serious issue that the world faces and has brought about results that affect life adversely (European Commission 2011). The major ones of these effects are average $0.8^{\circ} \mathrm{C}$ global warming above pre-industrial levels, $0.09{ }^{\circ} \mathrm{C}$ warming and acidifying of ocean since $1950 \mathrm{~s}, 3.2 \mathrm{~cm}$ sealevels rising per decade, an exceptional number of extreme heat waves in last decade, and drought affecting food crop growing areas (Levitus et al. 2012; Meyssignac and Cazenave 2012; McKechnie and Wolf 2010; Li et al. 2009; Heyder et al. 2011; Dai 2011). Unless the current mitigation, commitments, and pledges are fully implemented, the negative effects of climate change will go on. It is expected that a warming of $4{ }^{\circ} \mathrm{C}$ and sea-level rise of $0.5-1 \mathrm{~m}$ can occur as early as 2060s (Huddleston 2012).

The greenhouse effect is a natural process that plays a major role in shaping the earth's climate. Human activities, especially burning fossil fuels, have contributed to the enhancement of the natural greenhouse effect. This enhanced greenhouse effect stems from an increase in the atmospheric concentrations called greenhouse gases (Jain 1993; Saxena 2009). Greenhouse gases in the atmosphere lead to climate change. The major greenhouse gases emitted into the atmosphere through human activities are carbon dioxide, methane, nitrous oxide, and fluorinated gases (hydrofluorocarbons, perfluorocarbons, and sulfur hexafluoride) (Venkataraman et al. 2012; Wei et al. 2008; Lindley and McCulloch 2005). 
Carbon dioxide $\left(\mathrm{CO}_{2}\right)$ has the largest rate among the greenhouse gases, and it is the main reason of global warming. The global emission of carbon dioxide has reached 34 billion tons with an increase of $3 \%$ in 2011 (Olivier et al. 2012). Throughout the world, $\mathrm{CO}_{2}$ emissions are currently about 35,000 million metric tons per year. Unless the urgent policies are put in action, $\mathrm{CO}_{2}$ emissions will be projected to rise up 41,000 million metric tons per year in 2020s. In addition to warming in climate systems, the rising of $\mathrm{CO}_{2}$ concentration in the atmosphere leads ocean acidification as a result of dissolutions (The Potsdam Institute for Climate Impact Research and Climate 2012).

The Intergovernmental Panel on Climate Change (IPCC) stated in the Synthesis Report that, "In the absence of additional climate policies, an increase of baseline global greenhouse gas emissions from human sources would have become by a range from 25 to $90 \%$ between 2000 and 2030" (IPCC 2007). In the Fourth Assessment Report, IPCC has forecasted a global temperature rising between 1.1 and $6.4{ }^{\circ} \mathrm{C}$, and a global sea level rising between 7 and 23 inches by 2100 . According to the IPCC, global greenhouse gas emissions must be reduced to 50-85 \% below year 2000 levels by 2050 to limit warming to $2-2.4^{\circ} \mathrm{C}$. To be able to reach this target, greenhouse gas emissions from all sectors must be reduced through a multi-generational effort (IPCC 2007).

Transport is a main sector which causes the environmental pollution and climate change. Emissions from transport, and especially motor vehicles, add considerably to the levels of greenhouse gases in the atmosphere (OECD 2002). Transport is the second-largest sector in producing global $\mathrm{CO}_{2}$ emissions with a range of $22 \%$ (International Energy Agency 2012). Owing to the rapid increase of motor vehicles and very limited use of emission control technologies, transport emerges as the largest source of urban air pollution, which is an important public health problem in most cities of the developing world. Air pollution in developing countries accounts for tens of thousands of excess deaths and billions of dollars in medical costs and loses productivity every year (Faiz et al. 1996; Sivaloganathan 1998). The World Health Organization estimated that around 2.4 million people die every year due to air pollution (WHO 2007).

In today's world, environmental protection, climate change, and air pollution have become subjects of central concern. Many agencies, organizations (EPA, OECD, IPCC, IEA, EEA, etc.) worldwide were established and have been working to prevent air pollution and climate change caused by pollutant emissions. In their works, they have reported that approximately the 20-30\% of pollutant emissions originates from transport and these emissions have an important impact upon global warming and climate change. To prevent the effects of these pollutant emissions, they have emphasized on such issues as making several legal arrangements, advancing the technological developments, creating several model structures, developing control systems, and organizing the structure of traffic (OECD 2011; EPA 2012; IEA 2012; IPCC 2007; OECD 2002; EEA 2012).

Diesel engines have extensive usage compared to gasoline engines on account of their low-operating costs, energy efficiency, high durability, and reliability. They are the power source of commercial transport, being employed in trucks, buses, trains, and ships as well as off-road industrial vehicles such as excavation machinery and mining equipment. Although they have many advantages, they have a significant impact upon environmental pollution problems worldwide. Especially, diesel exhaust gas contains higher amount of particulate matter and $\mathrm{NO}_{\mathrm{x}}$ emissions that are responsible of severe environmental and health problems (Prasad and Bella 2010). Health experts have concluded that pollutants emitted by diesel engines affect human health adversely and cause acid rains, ground-level ozone, and reduce visibility. Studies have shown that exposure to diesel exhaust gas causes lung damage and respiratory problems, and there are concrete evidences that diesel emissions may cause cancer in humans (Sydbom et al. 2001; Lloyd and Cackette 2001; Whichmann 2006; Lewtas 2007; Burr and Gregory 2011).

This article presents a review on the pollutant emissions from diesel-engine vehicles and their control systems. In this context, four main pollutant emissions $\left(\mathrm{CO}, \mathrm{HC}, \mathrm{NO}_{\mathrm{x}}\right.$, and $\mathrm{PM}$ ) from diesel engines are explained individually. Worldwide emission control legislation is clarified and trends in emission control systems especially for heavyduty diesel engine vehicles are explained. Three different emission control systems are examined as diesel oxidation catalyst (DOC) to control $\mathrm{CO}$, and $\mathrm{HC}$ emissions, diesel particulate filter (DPF) to control PM emissions and selective catalytic reduction (SCR) to control $\mathrm{NO}_{\mathrm{x}}$ emissions.

\section{The emissions from diesel engines}

The diesel engine is an auto-ignition engine in which fuel and air are mixed inside the engine. The air required for combustion is highly compressed inside the combustion chamber. This generates high temperatures which are sufficient for the diesel fuel to ignite spontaneously when it is injected into the cylinder. Thus, the diesel engine uses heat to release the chemical energy contained in the diesel fuel and to convert it into mechanical force (Bosch 2005).

Carbon and hydrogen construct the origin of diesel fuel like most fossil fuels. For ideal thermodynamic equilibrium, the complete combustion of diesel fuel would only 


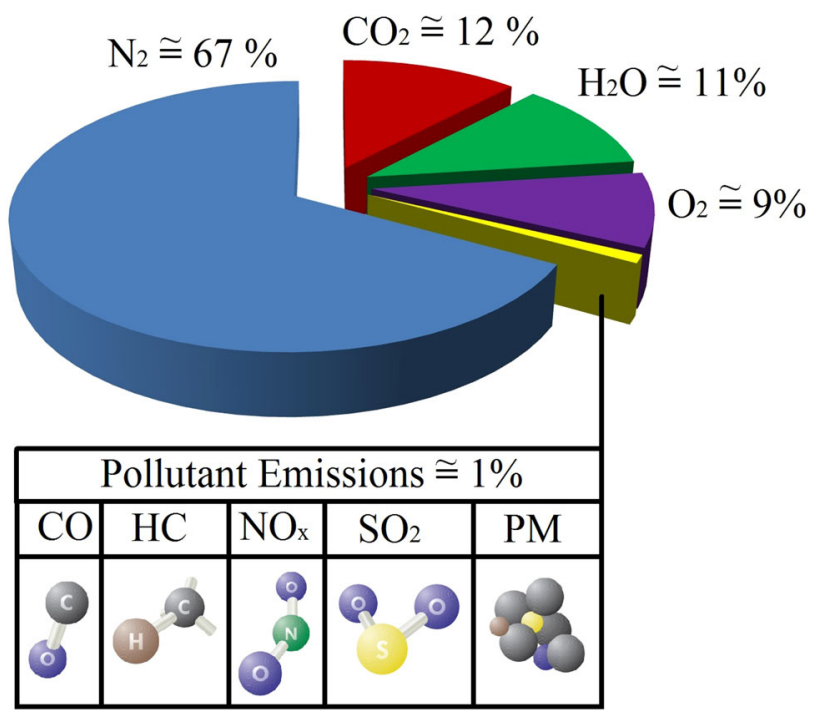

Fig. 1 The compositions of diesel exhaust gas

generate $\mathrm{CO}_{2}$ and $\mathrm{H}_{2} \mathrm{O}$ in combustion chambers of engine (Prasad and Bella 2010). However, many reasons (the airfuel ratio, ignition timing, turbulence in the combustion chamber, combustion form, air-fuel concentration, combustion temperature, etc.) make this out of question, and a number of harmful products are generated during combustion. The most significant harmful products are $\mathrm{CO}$, $\mathrm{HC}, \mathrm{NO}_{\mathrm{x}}$, and PM.

Figure 1 shows the approximate composition of diesel exhaust gas (Khair and Majewski 2006). Pollutant emissions have a rate of less than $1 \%$ in the diesel exhaust gas. $\mathrm{NO}_{\mathrm{x}}$ has the highest proportion of diesel pollutant emissions with a rate of more than $50 \%$. After $\mathrm{NO}_{\mathrm{x}}$ emissions, $\mathrm{PM}$ has the second highest proportion in pollutant emissions. Because diesel engines are lean combustion engines, and the concentration of $\mathrm{CO}$ and $\mathrm{HC}$ is minimal. Besides, pollutant emissions include a modicum of $\mathrm{SO}_{2}$ depending the specifications and quality of fuel. It is produced by the sulfates contained in diesel fuel. For the present, there is not any aftertreatment system like a catalytic converter to eliminate $\mathrm{SO}_{2}$. Nowadays, most of oil distributors and customers prefer ultra low sulfur diesel (ULSD) for diesel engines to prevent harmful effect of $\mathrm{SO}_{2}$.

In this section, the four main pollutant emissions $(\mathrm{CO}$, $\mathrm{HC}, \mathrm{PM}$, and $\mathrm{NO}_{\mathrm{x}}$ ) from diesel engine are explained. Each type of emission is investigated individually and the impacts of each emission on environmental and health problems are also revealed.

\section{Carbon monoxide (CO)}

Carbon monoxide results from the incomplete combustion where the oxidation process does not occur completely.
This concentration is largely dependent on air/fuel mixture and it is highest where the excess-air factor $(\lambda)$ is less than 1.0 that is classified as rich mixture (Wu et al. 2004). It can be caused especially at the time of starting and instantaneous acceleration of engine where the rich mixtures are required. In the rich mixtures, due to air deficiency and reactant concentration, all the carbon cannot convert to $\mathrm{CO}_{2}$ and be formed $\mathrm{CO}$ concentration. Although $\mathrm{CO}$ is produced during operation in rich mixtures, a small portion of $\mathrm{CO}$ is also emitted under lean conditions because of chemical kinetic effects (Faiz et al. 1996).

Diesel engines are lean combustion engines which have a consistently high air-fuel ratio $(\lambda>1)$. So, the formation of $\mathrm{CO}$ is minimal in diesel engines. Nevertheless, $\mathrm{CO}$ is produced if the droplets in a diesel engine are too large or if insufficient turbulence or swirl is created in the combustion chamber (Demers and Walters 1999).

Carbon monoxide is an odorless and colorless gas. In humans, $\mathrm{CO}$ in the air is inhaled by the lungs and transmitted into the bloodstream. It binds to hemoglobin and inhibits its capacity to transfer oxygen. Depending on CO concentration in the air, as thus leading to asphyxiation, this can affect the function of different organs, resulting in impaired concentration, slow reflexes, and confusion (Raub 1999; Kampa and Castanas 2008; Walsh 2011; Strauss et al. 2004).

\section{Hydrocarbons (HC)}

Hydrocarbon emissions are composed of unburned fuels as a result of insufficient temperature which occurs near the cylinder wall. At this point, the air-fuel mixture temperature is significantly less than the center of the cylinder (Demers and Walters 1999; Correa and Arbilla 2008). Hydrocarbons consist of thousands of species, such as alkanes, alkenes, and aromatics. They are normally stated in terms of equivalent $\mathrm{CH}_{4}$ content (Hiroyuki et al. 2011).

Diesel engines normally emit low levels of hydrocarbons. Diesel hydrocarbon emissions occur principally at light loads. The major source of light-load hydrocarbon emissions is lean air-fuel mixing. In lean mixtures, flame speeds may be too low for combustion to be completed during the power stroke, or combustion may not occur, and these conditions cause high hydrocarbon emissions (Zheng et al. 2008).

In Diesel engines, the fuel type, engine adjustment, and design affect the content of hydrocarbons. Besides, HC emissions in the exhaust gas depend on irregular operating conditions. High levels of instantaneous change in engine speed, untidy injection, excessive nozzle cavity volumes, and injector needle bounce can cause significant quantities of unburned fuel to pass into the exhaust (Payri et al. 2009). 
Unburned hydrocarbons continue to react in the exhaust if the temperature is above $600{ }^{\circ} \mathrm{C}$ and oxygen present, so hydrocarbon emissions from the tailpipe may be significantly lower than the hydrocarbons leaving the cylinder (Faiz et al. 1996).

Hydrocarbon emissions occur not only in the vehicle exhaust, but also in the engine crankcase, the fuel system, and from atmospheric venting of vapors during fuel distribution and dispensing (Faiz et al. 1996). Crankcase hydrocarbon emissions and evaporative losses of hydrocarbon emissions have, respectively, 20-35 and 15-25\% while tailpipe hydrocarbon emissions have 50-60\% of total hydrocarbon emissions (Dhariwal 1997).

Hydrocarbons have harmful effects on environment and human health. With other pollutant emissions, they play a significant role in the formation of ground-level ozone. Vehicles are responsible for about $50 \%$ of the emissions that form ozone. Hydrocarbons are toxic with the potential to respiratory tract irritation and cause cancer (Diaz-Sanchez 1997; Krzyzanowski et al. 2005).

\section{Particulate matter (PM)}

Particulate matter emissions in the exhaust gas are resulted from combustion process. They may be originated from the agglomeration of very small particles of partly burned fuel, partly burned lube oil, ash content of fuel oil, and cylinder lube oil or sulfates and water (Demers and Walters 1999; Maricq 2007). Most particulate matters are resulted from incomplete combustion of the hydrocarbons in the fuel and lube oil. In an experimental study, typical particle composition of a heavy-duty diesel engine is classified as $41 \%$ carbon, $7 \%$ unburned fuel, $25 \%$ unburned oil, $14 \%$ sulfate and water, $13 \%$ ash and other components (Kittelson 1998). In another study, It is reported that PM consists of elemental carbon $(\cong 31 \%)$, sulfates and moisture ( $\cong 14 \%$ ), unburnt fuel ( $\cong 7 \%$ ), unburnt lubricating oil ( $\cong 40 \%$ ) and remaining may be metals and others substances (Agarwal 2007).

Diesel particulate matters are typically spheres about 15-40 $\mathrm{nm}$ in diameter, and approximately more than $90 \%$ of PM is smaller than $1 \mu \mathrm{m}$ in diameter. The formation process of PM emissions is dependant on many factors as the combustion and expansion process, fuel quality (sulfur and ash content), lubrication oil quality, and consumption, combustion temperature, exhaust gas cooling (Burtscher 2005).

Particulate matter emissions from diesel engines are considerably higher (six to ten times) than from gasoline engines. Diesel particle emissions can be divided into three main components: soot, soluble organic fraction (SOF), and inorganic fraction (IF). More than $50 \%$ of the total PM emissions are soot that is seen as black smoke. SOF consists of heavy hydrocarbons adsorbed or condensed on the soot. It is derived partly from the lubricating oil, partly from unburned fuel, and partly from compounds formed during combustion. SOF values are too high at light engine loads when exhaust temperatures are low (Sarvi et al. 2011; Tighe et al. 2012; Metts et al. 2005; Stanmore et al. 2001; Sharma et al. 2005).

Many researches are performed to detect the impact of PM emissions on environment and human health. In these researches, It is documented that inhaling of these particles may cause to important health problems such as premature death, asthma, lung cancer, and other cardiovascular issues. These emissions contribute to pollution of air, water, and soil; soiling of buildings; reductions in visibility; impact agriculture productivity; global climate change (Englert 2004; OECD 2002; Michael and Kleinman 2000).

\section{Nitrogen oxides $\left(\mathrm{NO}_{\mathrm{x}}\right)$}

Diesel engines use highly compressed hot air to ignite the fuel. Air, mainly composed of oxygen and nitrogen, is initially drawn into the combustion chamber. Then, it is compressed, and the fuel is injected directly into this compressed air at about the top of the compression stroke in the combustion chamber. The fuel is burned, and the heat is released. Normally in this process, the nitrogen in the air does not react with oxygen in the combustion chamber and it is emitted identically out of the engine. However, high temperatures above $1,600{ }^{\circ} \mathrm{C}$ in the cylinders cause the nitrogen to react with oxygen and generate $\mathrm{NO}_{\mathrm{x}}$ emissions. So, it will not be wrong to say that the major influences of the formation of NOx are the temperature and concentration of oxygen in the combustion.

The amount of produced $\mathrm{NO}_{\mathrm{x}}$ is a function of the maximum temperature in the cylinder, oxygen concentrations, and residence time. Most of the emitted $\mathrm{NO}_{\mathrm{x}}$ is formed early in the combustion process, when the piston is still near the top of its stroke. This is when the flame temperature is the highest. Increasing the temperature of combustion increases the amount of $\mathrm{NO}_{\mathrm{x}}$ by as much as threefold for every $100{ }^{\circ} \mathrm{C}$ increase (Lee et al. 2013; Bosch 2005).

Nitrogen oxides are referred as nitrogen oxide (NO) and nitrogen dioxide $\left(\mathrm{NO}_{2}\right)$. NO constitutes $85-95 \%$ of $\mathrm{NO}_{\mathrm{x}}$. It is gradually converted to $\mathrm{NO}_{2}$ in atmospheric air. While $\mathrm{NO}$ and $\mathrm{NO} 2$ are lumped together as $\mathrm{NO}_{\mathrm{x}}$, there are some distinctive differences between these two pollutants. NO is a colorless and odorless gas, while NO2 is a reddish brown gas with pungent odor (Chong et al. 2010; Hoekman and Robbins 2012).

Road transport is the most important cause of urban $\mathrm{NO}_{\mathrm{x}}$ emissions worldwide contributing to 40-70 \% of the $\mathrm{NO}_{\mathrm{x}}$. Among various types of vehicles, diesel vehicles are the 
Table 1 Euro standards of European Union for heavy-duty vehicles (Delphi et al. 2012)

\begin{tabular}{lllll}
\hline & $\begin{array}{l}\mathrm{CO} \\
(\mathrm{g} / \mathrm{kWh})\end{array}$ & $\begin{array}{l}\mathrm{HC} \\
(\mathrm{g} / \mathrm{kWh})\end{array}$ & $\begin{array}{l}\mathrm{NO}_{\mathrm{x}} \\
(\mathrm{g} / \mathrm{kWh})\end{array}$ & $\begin{array}{l}\mathrm{PM} \\
(\mathrm{g} / \mathrm{kWh})\end{array}$ \\
\hline Euro I & 4.5 & 1.1 & 8.0 & 0.61 \\
Euro II & 4 & 1.1 & 7.0 & 0.15 \\
Euro III & 2.1 & 0.66 & 5.0 & 0.13 \\
Euro IV & 1.5 & 0.46 & 3.5 & 0.02 \\
Euro V & 1.5 & 0.46 & 2.0 & 0.02 \\
Euro VI & 1.5 & 0.13 & 0.4 & 0.01 \\
\hline
\end{tabular}

most important contributors to $\mathrm{NO}_{\mathrm{x}}$ emissions. Compared with gasoline engines, they need higher temperatures because they are compression-ignition engines. Diesel engines are responsible for about $85 \%$ of all the $\mathrm{NO}_{\mathrm{x}}$ emissions from mobile sources, primarily in the form of NO (Lee et al. 2013; Wang et al. 2012).

Nitrogen oxides emissions from vehicles are responsible for a large amount of environmental and health hazard. $\mathrm{NO}_{\mathrm{x}}$ emissions contribute to acidification, formation of ozone, nutrient enrichment, and smog formation, which have become considerable problems in most major cities worldwide (Grewe et al. 2012). In the atmosphere, $\mathrm{NO}_{\mathrm{x}}$ emissions react chemically with other pollutants to form tropospheric ozone (the primary component of photochemical smog) and other toxic pollutants.

$\mathrm{NO}$ and $\mathrm{NO}_{2}$ are considered as toxic; but $\mathrm{NO}_{2}$ has a level of toxicity five times greater than that of $\mathrm{NO}$ and it is also a direct concern of human lung disease. Nitrogen dioxide can irritate the lungs and lower resistance to respiratory infection (such as influenza). $\mathrm{NO}_{\mathrm{x}}$ emissions are important precursors to acid rain that may affect both terrestrial and aquatic ecosystems. Nitrogen dioxide and airborne nitrate also contribute to pollutant haze, which impairs visibility (Kagawa 2002; Hoeft et al. 2012).

\section{Emission control systems for diesel engine vehicles}

In today's world, environmental protection has advanced to become a topic of central concern. Many agencies and organizations are tried to prevent the damage on environment and human health caused by greenhouse gases and pollutant emissions. Due to the adverse effects of diesel emissions on health and environment, governments put forward to the requirements for permissible exhaust emission standards. Europe has developed Euro standards which have continuously been lowered since 1993 with the Euro I to Euro VI, respectively.

Table 1 shows Euro standards for M1 and M2, N1 and N2 vehicles as defined in Directive 70/156/EC with reference mass $\leq 2,610 \mathrm{~kg}$. The limits are defined in mass per energy $(\mathrm{g} / \mathrm{kWh})$ in this table. Regulations in Euro standards become progressively more stringent in the ensuing years. Compared to Euro I standard, Euro VI standard for CO, $\mathrm{HC}, \mathrm{NO}_{\mathrm{x}}$, and $\mathrm{PM}$ emissions was decreased, respectively, $66,76,95$, and $98 \%$. The implementation date of Euro VI standard for heavy-duty vehicles was 1 st of September 2014 (Delphi et al. 2012).

The emission values which have been more stringent day by day obliged the vehicle manufacturers to work on reducing pollutant emission from vehicles. In the studies that have been carried out for decades, engine modifications, electronic controlled fuel injections systems, and improvement fuel properties have been focused on. However, these measures have failed to achieve emission reduction determined by standards. The desired emission levels can be achieved only by means of aftertreatment emission control systems. Vehicles are equipped with emission control systems to meet the actual emissions standards and requirements. With emission control systems, pollutants from the exhaust can be eliminated after it leaves the engine, just before it is emitted into the air (Prasad and Bella 2010; Bosch 2005).

Among the emission control systems of diesel engines, most researches and studies have been carried out on reduction of $\mathrm{NO}_{\mathrm{x}}$ emissions because $\mathrm{NO}_{\mathrm{x}}$ content in exhaust of diesel engine has the highest percentage among the pollutant emissions. Of the researches so far, exhaust gas recirculation (EGR), lean $\mathrm{NO}_{\mathrm{x}}$ trap (LNT), and SCR are the most focused technologies to substantially eliminate the $\mathrm{NO}_{\mathrm{x}}$ emissions.

In EGR systems, to reduce $\mathrm{NO}_{\mathrm{x}}$ emissions, exhaust gas is recirculated back into the combustion chamber and mixed with fresh air at intake stroke. Consequently, the efficiency of combustion is worsened leading to the decrease of combustion temperature which means a reducing in $\mathrm{NO}_{\mathrm{x}}$ formations. EGR has a widely used range in diesel vehicles. However; it can not achieve singly high $\mathrm{NO}_{\mathrm{x}}$ conversion efficiency and reduction which meets current emission standards for especially heavy-duty vehicles. Also, due to the reduction of temperature in cylinder, this technology generates an increase of $\mathrm{HC}$ and CO emissions. (Bauner et al. 2009).

LNT technology, also called $\mathrm{NO}_{\mathrm{x}}$-storage-reduction (NSR) or $\mathrm{NO}_{\mathrm{x}}$ adsorber catalyst (NAC), has been developed to reduce $\mathrm{NO}_{\mathrm{x}}$ emission especially under lean conditions. During lean engine conditions, LNT stores $\mathrm{NO}_{\mathrm{x}}$ on the catalyst washcoat. Then, under the fuel-rich engine conditions it releases and reacts the $\mathrm{NO}_{\mathrm{x}}$ by the usual threeway type reactions. LNT catalyst mainly consists of three key components. These components are an oxidation catalyst $(\mathrm{Pt})$, a $\mathrm{NO}_{\mathrm{x}}$ storage ambiance (barium $(\mathrm{Ba})$ and/or other oxides), and a reduction catalyst (Rh). In LNT technology, Platinum-based catalysts are the most used 


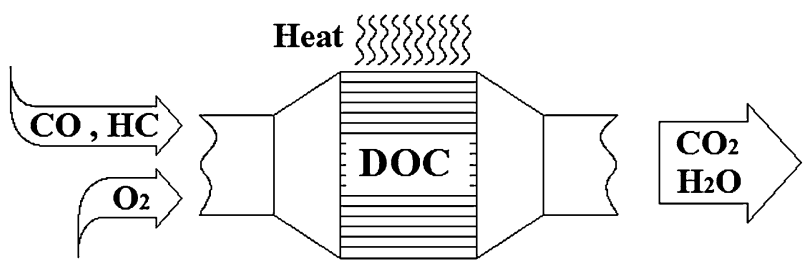

Fig. 2 Diesel oxidation catalyst

catalysts because of their $\mathrm{NO}_{\mathrm{x}}$ reduction at low temperature and stability in water and sulfur.

Like EGR technology, LNT technologies are insufficient to provide desired $\mathrm{NO}_{\mathrm{x}}$ emissions reduction. Apart from EGR and LNT technologies, it is possible to meet the current emissions standards with SCR technology. So, SCR technology is a respectable recent technology that many researchers are interested in.

In this section, emission control systems for diesel engines are explained particularly. Because of their extensive usage; DOC, DPF, and SCR systems especially for heavy-duty diesel engines are considered separately.

\section{Diesel oxidation catalyst (DOC)}

The main function of DOCs is to oxidize $\mathrm{HC}$ and $\mathrm{CO}$ emissions. Besides, DOCs play a role in decreasing the mass of diesel particulate emissions by oxidizing some of the hydrocarbons that are adsorbed onto the carbon particles (Chen and Schirmer 2003; Wang et al. 2008). DOCs may also be used in conjunction with SCR catalysts to oxidize $\mathrm{NO}$ into $\mathrm{NO}_{2}$ and increase the $\mathrm{NO}_{2}: \mathrm{NO}_{\mathrm{x}}$ ratio. There are three main reactions which occur in DOCs (Zheng and Banerjee 2009).

$\mathrm{CO}+1 / 2 \mathrm{O}_{2} \rightarrow \mathrm{CO}_{2}$

$\mathrm{C}_{3} \mathrm{H}_{6}+9 / 2 \mathrm{O}_{2} \rightarrow 3 \mathrm{CO}_{2}+3 \mathrm{H}_{2} \mathrm{O}$

$\mathrm{NO}+1 / 2 \mathrm{O}_{2} \rightarrow \mathrm{NO}_{2}$

$\mathrm{CO}$ and $\mathrm{HC}$ are oxidized to form $\mathrm{CO}_{2}$ and $\mathrm{H}_{2} \mathrm{O}$ [Eqs. (1), (2)] in the DOC (Fig. 2). Diesel exhaust gases generally contain $\mathrm{O}_{2}$, ranging from 2 to $17 \%$ by volume, which does not react with the fuel in the combustion chamber. This $\mathrm{O}_{2}$ is steadily consumed in DOC (Yu and Kim 2013).

Another chemical reaction that occurs in DOCs is the oxidizing of $\mathrm{NO}$ to form $\mathrm{NO}_{2}$ as seen in Eq. (3). $\mathrm{NO}_{2}$ concentration in the $\mathrm{NO}_{\mathrm{x}}$ is vital for downstream components like DPF and SCR. A high $\mathrm{NO}_{2}$ concentration in the $\mathrm{NO}_{\mathrm{x}}$ generates to increase efficiency of DPF and SCR. In the untreated engine exhaust gas, the $\mathrm{NO}_{2}$ component in the $\mathrm{NO}_{\mathrm{x}}$ is only about $10 \%$ at most operating points. With the function of the $\mathrm{DOC}, \mathrm{NO}_{2}: \mathrm{NO}$ rate is increased by inducing thermodynamic equilibrium (Lee et al. 2008; Sampara et al. 2007).
Temperature is an effective function on DOC efficiency. The effectiveness of the DOC in oxidizing $\mathrm{CO}$ and $\mathrm{HC}$ can be observed at temperatures above "light-off" for the catalytic activity. Light-off temperature is defined as the temperature where the reaction starts in catalyst and varies depending on exhaust composition, flow velocity, and catalyst composition.

DOC can also be used as a catalytic heater. The oxidation of $\mathrm{CO}$ and $\mathrm{HC}$ emissions generates to release heat. This heat is used to raise the exhaust-gas temperature downstream of DOC. The rising in the exhaust temperature supports DPF regeneration. In DOC, the temperature of the exhaust gas rises approximately above $90{ }^{\circ} \mathrm{C}$ for every $1 \%$ volume of $\mathrm{CO}$ oxidation. Since the temperature rise is very rapid, a steep temperature gradient becomes set in DOC. The resulting stress in the ceramic carrier and catalytic converter is limited to the permitted temperature hike of about $200-250{ }^{\circ} \mathrm{C}$ (Bosch 2005).

DOC is commonly a monolith honeycomb structure made of ceramic or metal. Besides this carrier structure, it consists of an oxide mixture (washcoat) composed of aluminum oxide $\left(\mathrm{Al}_{2} \mathrm{O}_{3}\right)$, cerium oxide $\left(\mathrm{CeO}_{2}\right)$, zirconium oxide $\left(\mathrm{ZrO}_{2}\right)$, and active catalytic noble metals such as platinum $(\mathrm{Pt})$, palladium $(\mathrm{Pd})$, and rhodium $(\mathrm{Rh})$. The primary function of the washcoat is to provide a large surface area for the noble metal, and to slow down catalyst sintering that occurs at high temperatures, leading to an irreversible drop in catalyst activity. The quantity of noble metals used for the coating, which often referred to as the loading, is specified in $\mathrm{g} / \mathrm{ft}^{3}$. The loading is approximately $50-90 \mathrm{~g} / \mathrm{ft}^{3}$. Currently, DOC containing Pt and Pd is most commonly used for oxidation and many studies conducted by researchers focused on these precious metal-based catalysts (Kolli et al. 2010; Kim et al. 2003; Wiebenga et al. 2012; Wang et al. 2008; Haneda et al. 2011).

The major properties in choice of DOCs are light-off temperature, conversion efficiency, temperature stability, and tolerance to poisoning and manufacturing costs. However, parameters as channel density (specified in cpsi (channels per square inch)), wall thickness of the individual channels, and the external dimensions of converter (crosssectional area and length) have a significant role on properties of DOCs. Channel density and wall thickness determine heat up response, exhaust-gas backpressure, and mechanical stability of the catalytic converter (Zervas 2008).

The volume of DOC $\left(\mathrm{V}_{\mathrm{c}}\right)$ is defined as a factor of exhaust-gas volumetric flow, which is itself proportional to the swept volume $(\mathrm{Vs})$ of the engine. Typical design figures for a $\mathrm{DOC}$ are $\mathrm{Vc} / \mathrm{Vs}=0.6-0.8$. The ratio of exhaust-gas volumetric flow $\left[\mathrm{V}_{\mathrm{f}}\left(\mathrm{m}^{3} / \mathrm{h}\right)\right]$ to catalyst volume $\left[\mathrm{V}_{\mathrm{c}}\left(\mathrm{m}^{3}\right)\right]$ is termed space velocity $\left[\mathrm{SV}\left(\mathrm{h}^{-1}\right)\right]$. Typical figures of $\mathrm{SV}$ for an oxidation catalyst are $150,000-250,000 \mathrm{~h}^{-1}$ (Bosch 2005). 


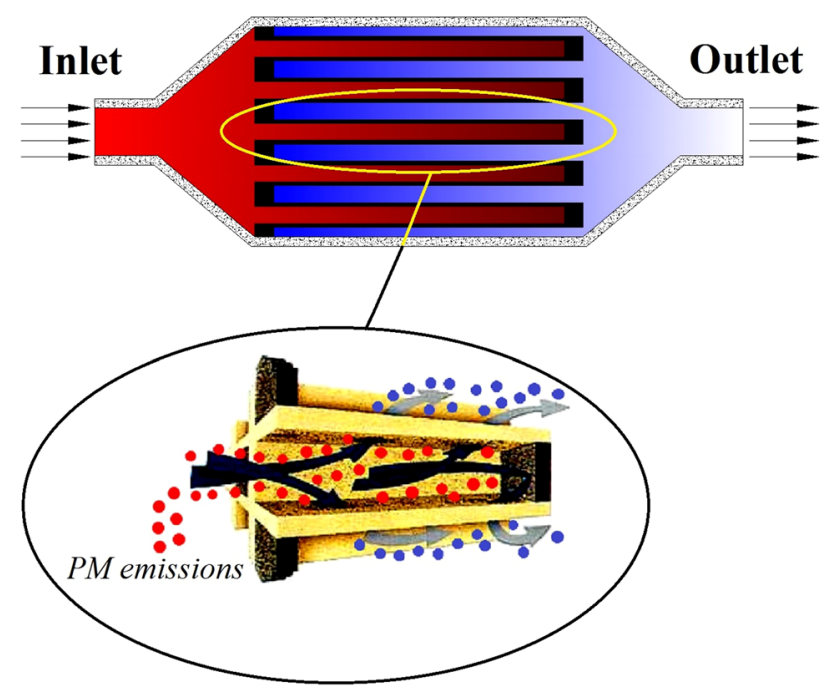

Fig. 3 Filtration of DPF

Since first introduction in 1970s, DOCs remain a key technology for diesel engines until nowadays (Wang et al. 2008). All new diesel engines mounted in passenger cars, light-duty and heavy-duty diesel vehicles are now equipped with DOCs. Reductions in emission from DOC use are estimated to be around $60-90 \%$ for HCs and CO.

DOCs are extensively preferred emission control systems not only for heavy-duty vehicles but also light-duty vehicles, in many countries such as Europe, USA, and Japan. The oxidation catalysts containing $\mathrm{Pt}$ and $\mathrm{Pd}$ are the most popular catalysts in world market. One of the major problems of these precious catalysts is that they carry reaction of $\mathrm{SO}_{2}$ to $\mathrm{SO}_{3}$ which consequently react with water and generates forms of sulfates and sulfuric acid. These forms have quite harmful effects like damaging the aftertreatment emission control systems as well as causing several environmental and health problems. There is no technology to prevent and eliminate these forms. Although ULSD is used in many countries worldwide, the problem could not be solved completely. Using alternative fuels as biodiesel, methyl alcohol etc., can completely reduce or eliminate this pollutant. Besides, it is possible to increase the conversion efficiency of DOC using of alternative fuels (Zhu et al. 2013).

\section{Diesel particulate filter (DPF)}

DPFs have been applied in the production of vehicles since 2000. They are used to remove PM emissions from the exhaust gas by physical filtration and usually made of either cordierite $\left(2 \mathrm{MgO}-2 \mathrm{Al}_{2} \mathrm{O}_{3}-5 \mathrm{SiO}_{2}\right)$ or silicon carbide ( $\mathrm{SiC})$ honeycomb structure monolith with the channels blocked at alternate ends. The plugged channels at each end force the diesel particulates matters through the porous substrate walls, which act as a mechanical filter (Fig. 3). As soot particles pass through the walls, they are transported into the pore walls by diffusion where they adhere. This filter has a large of parallel mostly square channels. The thickness of the channel walls is typically $300-400 \mu \mathrm{m}$. Channel size is specified by their cell density (Typical value: 100-300 cpsi) (Kuki et al. 2004; Ohno et al. 2002; Tsuneyoshi and Yamamoto 2012).

The filter walls are designed to have an optimum porosity, enabling the exhaust gases to pass through their walls without much hindrance, whilst being sufficiently impervious to collect the particulate species. As the filter becomes increasingly saturated with soot, a layer of soot is formed on the surface of the channel walls. This provides highly efficient surface filtration for the following operating phase. However, excessive saturation must be prevented. As the filters accumulate PM, it builds up backpressure that has many negative effects such as increased fuel consumption, engine failure, and stress in the filter. To prevent these negative effects, the DPF has to be regenerated by burning trapped PM.

There are subsequently two types of regeneration processes of DPFs commonly referred as active regeneration and passive regeneration. Active regeneration can be periodically applied to DPFs in which trapped soot is removed through a controlled oxidation with $\mathrm{O}_{2}$ at $550{ }^{\circ} \mathrm{C}$ or higher temperatures (Jeguirim et al. 2005). In an active regeneration of DPF, PM is oxidized periodically by heat supplied from outside sources, such as an electric heater or a flame-based burner. The burning of PMs, captured in the filter, takes place as soon as the soot loading in the filter reaches a set limit (about $45 \%$ ) indicated by pressure drop across the DPF.

The higher regeneration temperature and large amount of energy for heat supply are serious problems for active regeneration. While the temperatures as high as melting point of filter generates to failure of DPF, the necessity of energy for heating increases the production cost of system due to complex supplements. These negative effects regard the active regeneration as being out of preference.

Unlike in the active regeneration, in passive regeneration of DPF, the oxidation of PMs occurs at the exhaust gas temperature by catalytic combustion promoted by depositing suitable catalysts within the trap itself. PM is oxidized by an ongoing catalytic reaction process that uses no additional fuel. Under a temperature range between 200 and $450{ }^{\circ} \mathrm{C}$, small amounts of $\mathrm{NO}_{2}$ will promote the continuous oxidation of the deposited carbon particles. This is the basis of the continuously regenerating trap (CRT) which uses $\mathrm{NO}_{2}$ continuously to oxide soot within relatively low temperatures over a DPF (York et al. 2007, Allansson et al. 2002). 
In passive regeneration, the entire process is very simple, quiet, and effective and fuel efficient, that is, neither the vehicle operator nor the vehicle's engine management system has to do anything to induce the regeneration of the DPF. In this process generally, a wall flow silicon carbide filter is used with DOC, sophisticated engine management system and sensors. DOC upstream of DPF increases the ratio of $\mathrm{NO}_{2}$ to $\mathrm{NO}$ in the exhaust and lowers the burning temperature of PMs. $\mathrm{NO}_{2}$ provides a more effective oxidant than oxygen and so provides optimum passive regeneration efficiency (Johansen et al. 2007).

The wall flow $\mathrm{SiC}$ filter is one of the most widely used filters as DPF worldwide. Since the regeneration occurs at high exhaust temperatures, DOC has to be used upstream this filter. Catalyzed DPFs (CDPF) housing the DOC formulation on the DPF itself can eliminate this obligation. In this system, there is not any DOC or any aftertreatment systems upstream DPF and all reactions take place in the CDPF. CDPF in which Pt is used as catalyst has the same conversion efficiency compared to wall flow $\mathrm{SiC}$ filter. With CDPFs, the oxidation temperature of soot can be decreased. In addition to the oxidation occurring in DPF may be realized at lower temperatures, the conversion rate can be further increased using biodiesel or fuel additives (Lamharess et al. 2011). Although the regeneration is one of major problem for DPFs, nowadays many studies and researches have been carried out for solving this problem and decreasing the oxidation temperatures of soots.

\section{Selective catalytic reduction (SCR)}

SCR is another technology to reduce $\mathrm{NO}_{\mathrm{x}}$ emissions and especially improved for high-duty vehicles. Because of low exhaust temperature, it has not been used widely for lightduty vehicles. But nowadays, it is being developed for light-duty passenger vehicles and a few light-duty vehicle manufacturers like Audi have been using this technology in their automobile. SCR is used to minimize $\mathrm{NO}_{\mathrm{x}}$ emissions in the exhaust gas to utilize ammonia $\left(\mathrm{NH}_{3}\right)$ as the reductant (Biswas et al. 2009). Water and $\mathrm{N}_{2}$ are released as a result of catalytically conversion of $\mathrm{NO}_{\mathrm{x}}$ in the exhaust gas. Due to the toxic effects of $\mathrm{NH}_{3}$ and to prevent burning of $\mathrm{NH}_{3}$ in the warm atmosphere before the reaction, $\mathrm{NH}_{3}$ is provided from an aqueous solution of urea (Moreno-Tost et al. 2008; Hamada and Haneda 2012). This solution is obtained from mixing of $33 \%$ urea $\left(\mathrm{NH}_{2}\right)_{2} \mathrm{CO}$ and $67 \%$ pure water by mass.

In order to get high efficiency, the amount of $\mathrm{NH}_{3}$ stored on the SCR catalyst should be controlled as high as possible. However, high $\mathrm{NH}_{3}$ storage can lead to undesired ammonia. Ammonia slip is generally avoided or minimized by the precise injection of urea based on the required ammonia (Majewski and Khair 2006). By spraying solution on exhaust gas, as a result of the pure water vaporization, solid urea particles begin to melt and thermolysis takes place as seen in Eq. (4) (Koebel et al. 2000; Yim et al. 2004).

$\left(\mathrm{NH}_{2}\right)_{2} \mathrm{CO} \rightarrow \mathrm{NH}_{3}+\mathrm{HNCO}$ (thermolysis)

$\mathrm{NH}_{3}$ and isocyanic acid are formed in thermolysis reaction. $\mathrm{NH}_{3}$ takes part in the reactions of SCR catalyst, while the isocyanic acid is converted with water in a hydrolysis reaction (Koebel et al. 2000). Further $\mathrm{NH}_{3}$ is produced by this hydrolysis [Eq. (5)].

$\mathrm{HNCO}+\mathrm{H}_{2} \mathrm{O} \rightarrow \mathrm{NH}_{3}+\mathrm{CO}_{2}$ (hydrolysis)

Thermolysis and hydrolysis reactions occur more rapidly than SCR reactions. Two molecules of ammonia are produced in a molecular urea by reactions of thermolysis and hydrolysis (Chi and DaCosta 2005). The efficiency of reactions to produce $\mathrm{NH}_{3}$ from urea depends largely on exhaust gas temperature. While the temperature of urea melting is $133{ }^{\circ} \mathrm{C}$, it is indicated in different researches that thermolysis starts at $143,152,160{ }^{\circ} \mathrm{C}$ (Linde 2007; Oh et al. 2004; Sun et al. 2001; Schaber et al. 2004; Calabrese et al. 2000). Although the conversion of aqueous urea solution to $\mathrm{NH}_{3}$ is started at the time of injector spraying, full conversion is not completed by the entrance of the catalyst. Half of the total amount of decomposition of urea to $\mathrm{NH}_{3}$ is obtained up to entrance of catalyst. Thus, conversion efficiency is theoretically $50 \%$ to the catalyst entrance. However, the implementation of the hydrolysis reaction in the gas phase before the entrance of catalyst increases conversion efficiency due to exhaust temperature (Koebel et al. 2000; Chi and DaCosta 2005). After the thermolysis and hydrolysis, the chemical reactions which occur in SCR catalyst are shown below.

$$
\begin{aligned}
& 4 \mathrm{NO}+4 \mathrm{NH}_{3}+\mathrm{O}_{2} \rightarrow 4 \mathrm{~N}_{2}+6 \mathrm{H}_{2} \mathrm{O} \\
& 2 \mathrm{NO}+2 \mathrm{NO}_{2}+4 \mathrm{NH}_{3} \rightarrow 4 \mathrm{~N}_{2}+6 \mathrm{H}_{2} \mathrm{O} \\
& 6 \mathrm{NO}_{2}+8 \mathrm{NH}_{3} \rightarrow 7 \mathrm{~N}_{2}+12 \mathrm{H}_{2} \mathrm{O}
\end{aligned}
$$

The rate of SCR reactions may be listed as " $7>6>8$ ". The rate of reaction in Eq. (7) is higher than the other reactions. The reaction of Eq. (6) is realized in the absence of any oxidation catalyst before the SCR catalyst, namely $\mathrm{NO}_{\mathrm{x}}$ emissions in the form of NO. In the case of using a DOC with a high size and capacity before SCR catalyst, $\mathrm{NO}_{\mathrm{x}}$ emissions become in the form of $\mathrm{NO}$ and the reaction of Eq. (8) takes place. Therefore, the reaction rate decreases and a decline in conversion efficiency of $\mathrm{NO}_{\mathrm{x}}$ emissions are realized. The reaction of Eq. (7) will take place if the size and loading amount of the oxidation catalyst is optimized. Due to high rate of reaction, conversion of $\mathrm{NO}_{\mathrm{x}}$ emissions is actualized effectively. 1:1 of NO:NO2 ratio shows the maximum performance of SCR. For this 
Fig. 4 Typical SCR system with DOC

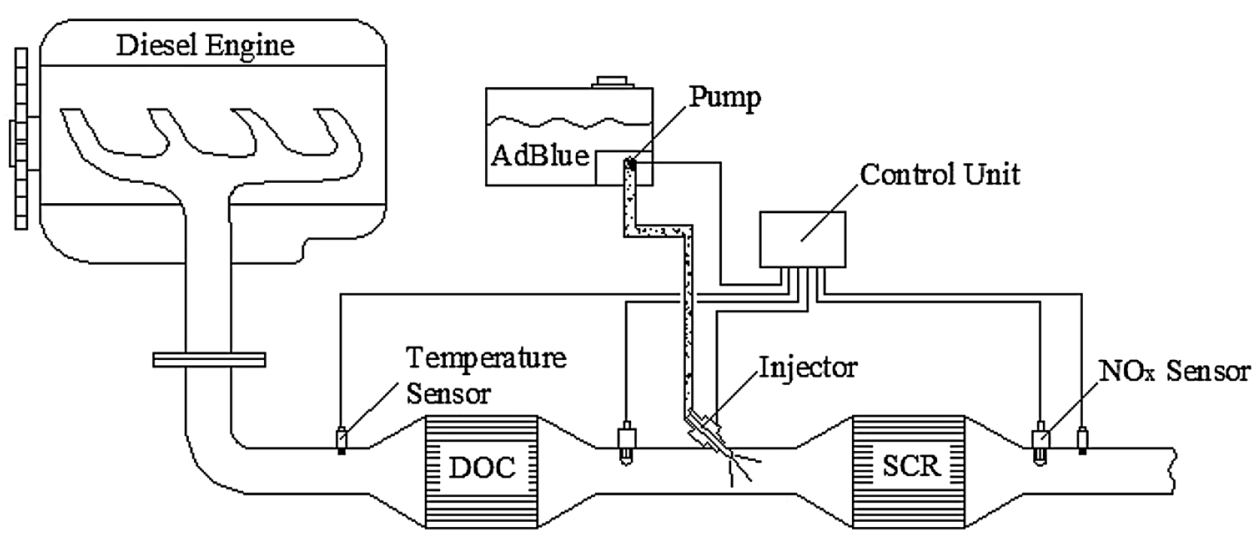

reason, it is necessary to set a NO:NO2 ratio of about 1:1 (Sluder et al. 2005; Devarakonda et al. 2008; Shost et al. 2008).

Figure 4 shows a typical SCR system with DOC. Zeolite- and vanadium-based catalysts are used in SCR systems. Temperature has a characteristic role in choosing catalyst. While copper-zeolites have the best low temperature performance, iron-zeolites have the best high temperature performance (Hamada and Haneda 2012).

SCR system can run in the temperature between 200 and $600{ }^{\circ} \mathrm{C}$. Reactions start generally at $200{ }^{\circ} \mathrm{C}$, and the maximum conversion efficiency is obtained at $350{ }^{\circ} \mathrm{C}$ (Way et al. 2009). The temperatures below $200{ }^{\circ} \mathrm{C}$ cause cyanide acid, biurea, melamine, amelide, and ameline due to decomposition reactions of urea solution. These components can accumulate in the exhaust pipe wall and lead to undesired results (Schaber et al. 2004). To prevent these formations, the spraying of urea solution starts at the exhaust gas temperature above $200{ }^{\circ} \mathrm{C}$. Besides, the temperatures above $600{ }^{\circ} \mathrm{C}$ cause $\mathrm{NH}_{3}$ to burn before reacting with the $\mathrm{NO}_{\mathrm{x}}$ emissions.

The researches on SCR systems have been intensified for system design, urea delivery system, catalyst, injection solution, injection pressure, and times.

$\mathrm{V}_{2} \mathrm{O}_{5}-\mathrm{WO}_{3} / \mathrm{TiO}_{2}, \mathrm{Fe}-\mathrm{ZSM} 5, \mathrm{Cu}-\mathrm{ZSM} 5$, and $\mathrm{Ag} / \mathrm{Al}_{2} \mathrm{O}_{3}$ are the most commonly used catalyst and many researches are focused on these catalyst types. Cu-PPHs, $\mathrm{CeO}_{2}-\mathrm{TiO}_{2}$, $\mathrm{Cu} / \mathrm{Al}_{2} \mathrm{O}_{3}, \mathrm{NbCe}$, and Fe-MFI are the other catalyst types that become a current issue. In many of the researches which were conducted on these catalysts, conversion efficiency of $\mathrm{NO}_{\mathrm{x}}$ emissions have been obtained more than $90 \%$ rates (Shan et al. 2012; Casapu et al. 2011; Oliveira et al. 2011). The catalysts based on $\mathrm{TiO}_{2}$ doped by Tungsten using Vanadium as active component are the most applied catalysts for SCR because of their high activity even at low temperature and high selectivity for $\mathrm{NO}_{2}$ as product. Zeolite is another base that may be used instead of $\mathrm{TiO}_{2}$, and has some differences at efficiency of $\mathrm{NO}_{\mathrm{x}}$ conversion. Unlike these bases, $\mathrm{Ag}-\mathrm{Al}_{2} \mathrm{O}_{3}$ catalysts have relatively low activity under the low exhaust temperature.

Urea injection quality and mixing are complex and critically important. Many studies have been carried out to determine the effect of urea droplet quality on conversion efficiency. It shows that urea injection is a significant parameter on conversion efficiency. It can affect conversion efficiency up to $10 \%$.

Although many amines (Methylamine, ethylamine, propylamine, and butylamine) have been tested as injection solution, no one could achieve the efficiency of urea solution named as AdBlue in markets worldwide (Stanciulescu et al. 2010). Other reductants, also, have been screened to substitute ammonia.

In SCR applications, hydrocarbons (HC) can be used as the reductant instead of ammonia or urea. This method is known as hydrocarbon SCR (HC-SCR), and many researches have been carried out on this method. Due to the existence of hydrocarbon in the exhaust gas (passive mode) or in the injected fuel itself (active mode), it is a relatively simple to apply it to the passenger vehicles. In diesel engines, the primary $\mathrm{HC}$ is diesel fuel, but other HCs such as ethanol, acetone, and propanol can be injected into the exhaust stream to aid in the reduction of $\mathrm{NO}_{\mathrm{x}} \cdot \mathrm{Ag}-\mathrm{Al}_{2} \mathrm{O}_{3}$ catalyst is the most promising catalyst for HC-SCR.

Compared with the emission control solutions (EGR, LNT, and SCR) to reduce $\mathrm{NO}_{\mathrm{x}}$ emissions, it has generally shown that SCR has the high efficiency in $\mathrm{NO}_{\mathrm{x}}$ conversion. Unlike LNT technology, SCR removes $\mathrm{NO}_{\mathrm{x}}$ continuously through the active reductant on the catalyst surface. Otherwise, LNT has a wide operating temperature window and lower desulfurization temperature. Because it leads to an increase in $\mathrm{HC}$ and $\mathrm{CO}$ emissions and low $\mathrm{NO}_{\mathrm{x}}$ conversion efficiency compared to SCR and LNT, EGR lags behind. In many applications, these technologies can be used as combination to increase $\mathrm{NO}_{\mathrm{x}}$ conversion efficiency (Xu and McCabe 2012; Lopez et al. 2009). 
With all other advanced aftertreatment devices, sulfur content in the combustion fuel is an important problem for SCR catalyst. The aftertreatment technologies are so sensitive to the sulfur content in the fuel. Sulfur content of the diesel fuel is included within the catalysts and begins to accumulate in the active sites of the catalyst, which lowers the catalytic activity. Although sulfates can be thermally decomposed, high temperatures $\left(>600{ }^{\circ} \mathrm{C}\right)$ are required to desulfurization under rich conditions. Alternative fuels and fuel additives have been used to prevent the effect of sulfurs on aftertreatment devices. It is possible to increase the emission reduction efficiencies of aftertreatment systems with fuels containing no sulfur. Especially biodiesel is the most used alternative fuel to prevent the sulfur damage, and many researches have been carried out on the use of biodiesel as an alternative fuel to diesel ( $\mathrm{Ng}$ et al. 2010).

\section{Conclusion}

This article reviews the characteristics of main pollutant emissions $\left(\mathrm{CO}, \mathrm{HC}, \mathrm{PM}\right.$, and $\left.\mathrm{NO}_{\mathrm{x}}\right)$ from diesel engines and control technologies of these pollutant emissions with standards and regulations. Among these pollutant emission, $\mathrm{CO}$ and $\mathrm{HC}$ are emitted because of incomplete combustion and unburned fuel while $\mathrm{NO}_{\mathrm{x}}$ emissions are caused because of high combustion temperatures above $1,600{ }^{\circ} \mathrm{C}$. As for PM emissions, the reasons of PM emissions are agglomeration of very small particles of partly burned fuel, partly burned lube oil, ash content of fuel oil and cylinder lube oil or sulfates and water. These pollutant emissions have harmful effects on environment and human health. Even though many applications have been implemented on diesel engines to prevent harmful effects of these pollutant emissions and to meet stringent emission regulations, only aftertreatment emission control systems are of the potential to eliminate the pollutant emissions from diesel exhaust gas. To control these pollutant emissions as desired is only possible with aftertreatment systems. Diesel exhaust aftertreatment systems include DOC, DPF, and SCR. These systems are the most requested components especially for heavy-duty diesel engines and usually a combination of DOC, DPF, and SCR has been respectively used for the simultaneous removal of main pollutant emissions from diesel engine exhaust.

DOCs are used not only to reduce $\mathrm{CO}$ and $\mathrm{HC}$ emissions, but also to exert a considerable influence on the performance of downstream DPF and SCR. DOCs increase the exhaust temperature for DPF regeneration and convert $\mathrm{NO}$ to $\mathrm{NO}_{2}$ for increasing conversion efficiency of SCR systems. DPFs are used generally with DOC to eliminate PM emissions from diesel exhaust gas. They are typically constructed from cordierite $\mathrm{SiC}$. This structure acts as a mechanical filter and eliminates PM emissions from diesel exhaust gas by \%100. SCR systems are highly effective to reduce $\mathrm{NO}_{\mathrm{x}}$ emissions. $\mathrm{NH}_{3}$ is used as a reductant and injects on exhaust gas to convert $\mathrm{NO}_{\mathrm{x}}$ emissions to $\mathrm{N}_{2}$ form. $\mathrm{NH}_{3}$ is obtained from a urea solution known as AdBlue in the market. Pt- and Pd-based catalysts are the most commonly used catalyst for DOC and SCR. The temperature of diesel exhaust gas has an important effect on reducing pollutant emissions. Besides catalyst type, space velocity of exhaust gas, and emission form are the other parameters affecting the efficiency.

With the aftertreatment emission control systems, it is possible to reduce the damage of the pollutant emissions on air pollution, to meet emission standards and requirements, and to prevent the harmful effects of pollutant emissions on environment and human health. Due to these missions, emission control systems are utmost importance worldwide. For the complete destruction of polluting emissions from diesel engines, further studies and researches on the aftertreatment emission control systems should be intensified and continued.

Open Access This article is distributed under the terms of the Creative Commons Attribution License which permits any use, distribution, and reproduction in any medium, provided the original author(s) and the source are credited.

\section{References}

Agarwal AK (2007) Biofuels (alcohols and biodiesel) applications as fuels for internal combustion engines. Prog Energy Combust Sci 33:233-271

Allansson R, Blakeman PG, Cooper BJ, Phillips PR, Thoss JE, Walker AP (2002) The use of the continuously regenerating trap (CRTTM) to control particulate emissions: minimising the impact of sulfur poisoning. Society of Automotive Engineers, 2002-01-1271

Bauner D, Laestadius S, Iida N (2009) Evolving technological systems for diesel engine emission control: balancing GHG and local emissions. Clean Technol Environ Policy 11:339-365

Biswas S, Verma V, Schauer JJ, Sioutas C (2009) Chemical speciation of PM emissions from heavy-duty diesel vehicles equipped with diesel particulate filter (DPF) and selective catalytic reduction (SCR) retrofits. Atmos Environ 43: 1917-1925

Bosch (2005) Emissions-control technology for diesel engines. Robert Bosch GmbH, Germany

Burr M, Gregory C (2011) Vehicular exhaust. Encylopedia Environ Health 49:645-563

Burtscher H (2005) Physical characterization of particulate emissions from diesel engines: a review. Aerosol Sci 36:896-932

Calabrese JL, Patchett JA, Grimston K, Rice GW, Davis GW (2000) The influence of injector operating conditions on the performance of a urea-water selective catalytic reduction (SCR) system. SAE technical paper, 2000-01-2814

Casapu M, Bernhard A, Peitz D, Mehring M, Elsener M, Kröcher O (2011) A Niobia-Ceria based multi-purpose catalyst for selective catalytic reduction of $\mathrm{NO}_{\mathrm{x}}$, urea hydrolysis and soot oxidation in diesel exhaust. Appl Catal B 103:79-84 
Chen M, Schirmer K (2003) A modelling approach to the design optimization of catalytic converters of I. C. engines. In: Proceedings of ICEF03: 2003 fall technical conference of the ASME internal combustion engine division, ICEF2003-729

Chi JN, DaCosta HFM (2005) Modelling and control of a urea-SCR aftertreatment system. SAE technical paper, 2005-01-0969

Chong JJ, Tsolakis A, Gill SS, Theinnoi K, Golunski SE (2010) Enhancing the NO2/NOx ratio in compression ignition engines by hydrogen and reformate combustion, for improved aftertreatment performance. Int J Hydrog Energy 35:8723-8732

Correa SM, Arbilla G (2008) Carbonly emissions in diesel and biodiesel exhauts. Atmos Environ 42:769-775

Dai A (2011) Drought under global warming: a review. Wiley Interdiscip Rev Clim Chang 2(1):45-65

Delphi (2012) Worldwide emissions standards-heavy duty and offhighway vehicles. Delphi, Michigan

Demers D, Walters G (1999) Guide to exhaust emission control options. BAeSAME, Bristol

Devarakonda M, Parker G, Johnson JH, Strots V, Santhanam S (2008) Model-based estimation and control system development in an urea-SCR aftertreatment system. SAE-Worldcongress, 01-1324

Dhariwal HC (1997) Control of blowby emissions and lubricating oil consumption in I.C. engines. Energy Convers Manag 38:1267-1274

Diaz-Sanchez D (1997) The role of diesel exhaust particles and their associated polyaromatic hydrocarbons in the induction of allergic airway disease. Allergy 52:52-56

Englert N (2004) Fine particles and human health-a review of epidemiological studies. Toxicol Lett 149:235-242

Environmental Protection Agency (EPA) (2012) Climate change indicators in the United States. EPA, Washington

European Commission (2011) Climate change: report. Europe: Directorate-General for Communication, Brussels

European Environment Agency (EEA) (2012) Annual European Union greenhouse gas inventory 1990-2000 and inventory report 2012. Copenhagen

Faiz A, Weaver CS, Walsh PW (1996) Air pollution from motor vehicles: standards and texhnologies for controlling emissions. The World Bank, Washington

Grewe V, Dahlmann K, Matthes S, Steinbrecht W (2012) Attributing ozone to NOx emissions: implications for climate mitigation measures. Atmos Environ 59:102-107

Hamada H, Haneda M (2012) A review of selective catalytic reduction of nitrogen oxides with hydrogen and carbon monoxide. Appl Catal A 421-422:1-13

Haneda M, Sasaki M, Hamada H, Ozawa M (2011) Platinum-based catalyst for diesel hydrocarbon oxidation. Chin J Catal 32:777-781

Heyder U, Schaphoff S, Gerten D, Lucht W (2011) Risk of severe climate change impact on the terrestrial biosphere. Environ Res Lett 6:034036

Hiroyuki Y, Misawa K, Suzuki D, Tanaka K, Matsumoto J, Fujii M, Tanaka K (2011) Detailed analysis of diesel vehicle exhaust emissions: nitrogen oxides, hydrocarbons and particulate size distributions. Proc Combust Inst 33:2895-2902

Hoeft I, Steude K, Wrage N, Veldkamp E (2012) Response of nitrogen oxide emissions to grazer species and plant species composition in temperate agricultural grassland. Agric Ecosyst Environ 151:34-43

Hoekman SK, Robbins C (2012) Review of the effects of biodiesel on NOx emissions. Fuel Process Technol 96:237-249

Huddleston N (2012) Climate change: evidence, impacts and choices. National Research Council

Intergovernmental Panel on Climate Change (IPCC) (2007) Climate change 2007: synthesis report. Valencia, Spain

International Energy Agency (IEA), 2012. $\mathrm{CO}_{2}$ Emissions From Fuel Combustion Highlights. France
Jain PC (1993) Greenhouse effect and climate change: scientific basis and overview. Renew Energy 3:403-420

Jeguirim M, Tschamber V, Brilhac JF, Ehrburger P (2005) Oxidation mechanism of carbon black by $\mathrm{NO}_{2}$ : effect of water vapour. Fuel 84:1949-1956

Johansen K, Dahl S, Mogensen G, Pehrson S, Schramm J, Ivarsson A (2007) Novel base metal-palladium catalytic diesel filter coating with $\mathrm{NO}_{2}$ reducing properties. Society of Automotive Engineers, 2007-01-1921

Kagawa J (2002) Health effects of diesel exhaust emissions-a mixture of air pollutants of worldwide concern. Toxicology 181-182:349-353

Kampa M, Castanas E (2008) Human health effects of air pollution. Environ Pollut 151:362-367

Khair MK, Majewski WA (2006) Diesel emissions and their control. SAE Inernational. ISBN: 978-0-7680-0674-2

Kim MR, Kim DH, Woo SI (2003) Effect of V2O5 on the catalytic activity of Pt-based diesel oxidation catalyst. Appl Catal B 45:269-279

Kittelson DB (1998) Engines and nanoparticles: a review. J Aerosol Sci 29(5-6):575-588

Koebel M, Elsener M, Kleemann M (2000) Urea-SCR: a promising technique to reduce NOx emissions from automotive diesel engines. Catalyst Today 59:335-345

Kolli T, Kanerva T, Huuhtanen M, Vippola M, Kallinen K, Kinnunen T, Lepisto T, Lahtinen J, Keiski R (2010) The activity of Pt/ $\mathrm{A} 12 \mathrm{O} 3$ diesel oxidation catalyst after sulphur and calcium treatments. Catal Today 154:303-307

Krzyzanowski M, Kuna-Dibbert B, Schneider J (2005) Health effects of transport-related air pollution. WHO, Denmark

Kuki T, Miyairi Y, Kasai Y, Miyazaki M, Miwa S (2004) Study on reliability of wall-flow-type diesel particulate filter. SAE, 2004-01-0959

Lamharess N, Millet CN, Starck L, Jeudy E, Lavy J, Costa PD (2011) Catalysed diesel particulate filter: study of the reactivity of soot arising from biodiesel combustion. Catal Today 176:219-224

Lee SJ, Jeong SJ, Kim WS, Lee CB (2008) Conputational study on the effects of volume ratio of DOC/DPF and catalyst loading on the PM and NOx emission control for heavy-duty diesel engines. Int J Automot Technol 9:0-11

Lee T, Park J, Kwon S, Lee J, Kim J (2013) Variability in operationbased NOx emission factors with different test routes, and its effects on the real-driving emissions of light diesel vehicles. Sci Total Environ 461-462:377-385

Levitus S, Antonov JI, Boyer TP, Baranova OK, Garcia HE, Locarnini RA, Mishonov AV, Reagan JR, Seidov D, Yarosh ES, Zweng MM (2012) World ocean heat content and thermosteric sea level change (0-2000 m), 1955-2010. Geophys Res Lett 39:110603

Lewtas J (2007) Air pollution combustion emissions: characterization of causative agents and mechanisms associated with cancer, reproductive, and cardiovascular effects. Mutat Res Rev Mutat Res 636:95-133

Li Y, Ye W, Wang M, Yan X (2009) Climate change and drought: a risk assessment of crop-yield impacts. Clim Res 39:31-46

Linde DR (2007) CRC handbook of chemistry and physics, 87th edn. Taylor \& Francis, Boca Rato

Lindley AA, McCulloch A (2005) Regulating to reduce emissions of fluorinated greenhouse gases. J Fluorine Chem 126:1457-1462

Lloyd AC, Cackette TA (2001) Diesel engines: environmental impact and control. J Air Waste Manag Assoc 51:809-847

Lopez JM, Jimenez F, Aparicio F (2009) On-road emissions from urban buses with SCR + Urea and EGR + DPF systems using diesel and biodiesel. Transp Res Part D 14:1-5

Majewski WA, Khair MK (2006) Diesel emissions and their control. SAE International, Warrendale. ISBN 10: 0-7680-0674-0 
Maricq MM (2007) Chemical characterization of particulate emissions from diesel engines: a review. Aerosol Sci 38:1079-1118

McKechnie AE, Wolf BO (2010) Climate change increases the likelihood of catastrophic avian mortality events during extreme heat waves. Biol Lett 6:253-256

Metts TA, Batterman SA, Fernandes GI, Kalliokosi P (2005) Ozone removel by diesel particulate matter. Atmos Environ 39:3343-3354

Meyssignac B, Cazenave A (2012) Sea level: a review of present-day and recent-past changes and variability. J Geodyn 58:96-109

Michael RA, Kleinman MT (2000) Incidence and apparent health significance of brief airborne particle excursions. Aerosol Sci Technol 32:93-105

Moreno-Tost R, Oliveira MS, Eliche-Quesada D, Jiménez-Jiménez J, Jiménez-López A, Rodríguez-Castellón E (2008) Evaluation of $\mathrm{Cu}-\mathrm{PPHs}$ as active catalysts for the SCR process to control $\mathrm{NO}_{\mathrm{x}}$ emissions from heavy duty diesel vehicles. Chemosphere 72:608-615

$\mathrm{Ng} \mathrm{JH}, \mathrm{Ng} \mathrm{HK}$, Gan S (2010) Advances in biodiesel fuel for application in compression ignition engines. Clean Technol Environ Policy 12:459-493

Oh TY, Ko JH, Seong HJ, Min BS (2004) Design optimization of the mixing chamber in SCR system for marine diesel engine. In: 6th international symposium on diagnostics and modeling of combustion in internal combustion engines 6, pp 87-92

Ohno K, Taoka N, Furuta T, Kudo A, Komori T (2002) Characterization of high porosity SiC-DPF. SAE, 2002-01-0325

Oliveira MLM, Silva CM, Moreno-Test R, Farias TL, Jimenez-Lopez A, Rodriguez-Castellon $\mathrm{E}$ (2011) Modelling of $\mathrm{NO}_{\mathrm{x}}$ emission factors from heavy and light-duty vehicles equipped with advanced aftertreatment systems. Energy Convers Manag 52:2945-2951

Olivier JGJ, Maenhout GJ, Peters JAHW (2012) Trends in global $\mathrm{CO}_{2}$ emissions-2012 report. Netherlands Environmental Assessment Agency, Hague

Organisation for Economic Co-Operation and Develeopment (OECD) (2002) Strategies to reduce greenhouse gas emissions from road transport: analytical methods. OECD, Paris

Organisation for Economic Co-Operation and Develeopment (OECD) (2011) Environmental outlook to 2050 - climate change chapter

Payri F, Bermudez VR, Tormos B, Linares WG (2009) Hydrocarbon emissions speciation in diesel and biodiesel exhausts. Atmos Environ 43:1273-1279

Prasad R, Bella VR (2010) A review on diesel soot emission, its effect and control. Bull Chem React Eng Catal 5(2):69-86

Raub JA (1999) Health effects of exposure to ambient carbon monoxide. Chemosphere: global change. Science 1:331-351

Sampara CS, Bissett EJ, Chmielewski M, Assanis D (2007) Global kinetics for platinum diesel oxidation catalysts. Ind Eng Chem Res 46:7993-8003

Sarvi A, Lyyranen J, Jokiniemi J, Zevenhoven R (2011) Particulate emissions from large-scale medium-speed diesel engines: 1. Particle size distribution. Fuel Process Technol 92:1855-1861

Saxena AK (2009) Greenhouse gas emissions-estimation and reduction. Asian Productivity Organization, India

Schaber P, Colson J, Higgins S, Thielen D, Anspach B, Brauer J (2004) Thermal decomposition (pyrolysis) of urea in an open reaction vessel. Thermochim Acta 424:131-142

Shan W, Liu F, He H, Shi X, Zhang C (2012) An environmentallybenign $\mathrm{CeO} 2-\mathrm{TiO} 2$ catalyst for the selective catalytic reduction of $\mathrm{NOx}$ with $\mathrm{NH} 3$ in simulated diesel exhaust. Catal Today 184:160-165

Sharma M, Agarwal AK, Bharathi KV (2005) Characterization of exhaust particulates from diesel engine. Atmos Environ 39:3023-3028

Shost M, Noetzel J, Wu M-C, Sugiarto T, Bordewyk T, Fulks G, Fisher GB (2008) Monitoring, feedback and control of urea SCR dosing systems for $\mathrm{NO}_{\mathrm{x}}$ reduction: utilizing an embedded model and ammonia sensing. SAE World Congress, 2008-01-1325

Sivaloganathan S (1998) Case report: death from diesel fumes. J Clin Forensic Med 5:138-139

Sluder SC, Storey J, Lewis S, Lewis L (2005) Low temperature urea decomposition and SCR performance. SAE technical paper, 2005-01-1858

Stanciulescu M, Charland JP, Kelly JF (2010) Effect of primary amine hydrocarbon chain length for the selective catalytic reduction of NOx from diesel engine exhaust. Fuel 89:2292-2298

Stanmore BR, Brilhac JF, Gilot P (2001) The oxidation of soot: a review of experiments, mechanisms and models. Carbon 39:2247-2268

Strauss S, Wasil JR, Earnest GS (2004) Carbon monoxide emissions from marine outboard engines. Society of Automotive Engineers, 2004-32-0011

Sun WH, Boyle JM, Carmignani PG, Sassenrath JM (2001) Small scale test results from new selective catalytic $\mathrm{NO}_{\mathrm{x}}$ reduction process using urea. MEGA Symposium, Chicago

Sydbom A, Blomberg A, Parnia S, Stenfors N, Sandstrom T, Dahlen SE (2001) Health effects of diesel exhaust emissions. Eur Respir 17:733-746

The Potsdam Institute for Climate Impact Research and Climate (2012) Turn down the heat: Why a $4^{\circ} \mathrm{C}$ warmer world must be avoided. The World Bank, Washington

Tighe CJ, Twigg MV, Hayhurst AN, Dennis JS (2012) The kinetics of oxidation of diesel soots by $\mathrm{NO}_{2}$. Combust Flame 159:77-90

Tsuneyoshi K, Yamamoto K (2012) A study on the cell structure and the performances of wall-flow diesel particulate filter. Energy 48:492-499

Venkataraman SV, Iniyan S, Goic R (2012) A review of climate change, mitigation and adaptation. Renew Sustain Energy Rev $16: 878-897$

Walsh MP (2011) Mobile source related air pollution: effects on health and the environment. Encyclopedia of Environ Health 3:803-809

Wang TJ, Baek SW, Lee JH (2008) Kinetic parameter estimation of a diesel oxidation catalyst under actual vehicle operating conditions. Ind Eng Chem Res 47:2528-2537

Wang X, Wasterdahl D, Jingnan H, Wu Y, Yin H, Pan X, Zhang KM (2012) On-road diesel vehicle emission factors for nitrogen oxides and black carbon in two Chinese cities. Atmos Environ 46:45-55

Way P, Viswanathan K, Preethi P, Gilb A, Zambon N, Blaisdell J (2009) SCR performance optimization through advancements in aftertreatment packaging. SAE-Worldcongress, 01-0633

Wei Z, Jiangming M, Yunting F, Xiankai L, Hui W (2008) Effects of nitrogen deposition on the greenhouse gas fluxes from forest soils. Acta Ecol Sin 28(5):2309-2319

Whichmann HE (2006) Environmental pollutants: diesel exhaust particles. Encyclopedia Respir Med 1:96-100

Wiebenga MH, Kim CH, Schmieg SJ, Oh SH, Brown DB, Kim DH, Lee JH, Peden CHF (2012) Deactivation mechanisms of Pt/Pdbased diesel oxidation catalysts. Catal Today 184:197-204

World Health Organization (2007) Estimated deaths \& DALYs attributable to selected environmental risk factors, by WHO member state. Department of Public Health \& Environnment

Wu CW, Chen RH, Pu JY, Lin TH (2004) The influence of air-fuel ratio on engine performance and pollutant emission of an SI engine using ethanol-gasoline-blended fuels. Atmos Environ 38:7093-7100

Xu L, McCabe RW (2012) LNT + in situ SCR catalyst system for diesel emissions control. Catal Today 184:83-94

Yim SD, Kim SJ, Baik JH, Nam IS, Mok YS, Lee JH, Cho BK, Oh SH (2004) Decomposotion of urea into $\mathrm{NH}_{3}$ for the SCR Process. Ind Eng Chem Res 43:4856-4863 
York APE, Ahmadinejad M, Watling TC, Walker AP, Cox JP, Gast J, Blakeman PG, Allansson R (2007) Modeling of the catalyzed continuously regenerating diesel particulate filter (CCR-DPF) system: model development and passive regeneration studies. Society of Automotive Engineers, 2007-01-0043

Yu BK, Kim MY (2013) Modeling the selective catalytic reduction of NOx by ammonia over a Vanadia-based catalyst from heavy duty diesel exhaust gases. Appl Therm Eng 50:152-158

Zervas E (2008) Impact of different configurations of a diesel oxidation catalyst on the $\mathrm{CO}$ and $\mathrm{HC}$ tail-pipe emissions of a Euro 4 passenger car. Appl Therm Eng 28:962-966
Zheng M, Banerjee S (2009) Diesel oxidation catalyst and particulate filter modeling in active-flow configurations. Appl Therm Eng 29:3021-3035

Zheng M, Mulenga MC, Reader GT, Wang M, Ting DS, Tjong J (2008) Biodiesel engine performance and emissions in low temperature combustion. Fuel 87:714-722

Zhu L, Cheung CS, Zhang WG, Fang JH, Huang Z (2013) Effects of ethanol-biodiesel blends and diesel oxidation catalyst (DOC) on particulate and unregulated emissions. Fuel 113:690-696 